\title{
Pengguna Dadah Wanita di Malaysia: Pengalaman Penagihan dan Hubungan Kekeluargaan
}

\author{
Fauziah Ibrahim*, Ezarina Zakaria, Salina Nen, Norulhuda Sarnon, Nor Jana Saim \\ Pusat Pengajian Psikologi dan Pembangunan Manusia, Fakulti Sains Sosial dan Kemanusiaan, Universiti Kebangsaan Malaysia, 43600, Bangi, Selangor
}

*Corresponding author: fauziahukm@gmail.com

\section{Article history}

Received :22 February 2013

Received in revised form

16 December 2013

Accepted :15 February 2014

\begin{abstract}
Women involvement in drug abuse has adverse impacts not only to the nation but also impose great challenges to achieve stable family structures. Therefore, this article aims to explore the experiences of women drug user in Malaysia with reference to their drug abuse activity and identify the level of family relationship they possess. This research used quantitative method and cross-sectional survey. A total of 120 women at the Center of Drugs Recovery and Narcotic Rehabilitation (PUSPEN), Bachok, Kelantan were chosen using stratified random sampling. Data were analyzed using descriptive analysis. The results of the study showed that 39.5 percent of women inmates started getting involved in drug activities at the age of 15-20 years, 79 percent had been arrested for the first time to undergo a rehabilitation process, majority of them (54.6 percent) reported to use drugs on regular basis and more than half of the respondents (63 percent) admitted that they obtained drugs supplies from drug dealers. Analysis of drug using pattern reveals that syabu ( 75.6 percent) and heroin ( 61.3 percent) are the most popular drugs used by the inmates. Finding also showed that majority ( 60.5 percent) of drug inmates engaged in moderate level of family relationship. Findings from this research yielded wide implications to improve drug abuse treatment and rehabilitation programs in an institution, particularly among women drug users in Malaysia.

Keywords: Drugs inmates; women; the experience of drug addiction; family relationships

Abstrak

Penglibatan wanita dengan kegiatan penyalahgunaan dadah telah memberi kesan negatif bukan sahaja kepada negara tetapi memberi cabaran besar ke arah pencapaian matlamat pembentukan keluarga sejahtera. Oleh itu, artikel ini disediakan bertujuan untuk meninjau pengalaman penyalahgunaan dadah dan mengenal pasti tahap hubungan kekeluargaan pengguna dadah wanita di Malaysia. Kajian ini dijalankan dengan menggunakan reka bentuk tinjauan keratan-lintang (cross-sectional survey) secara kuantitatif. Seramai 120 orang penghuni dadah wanita dari Pusat Pemulihan dan Penagihan Narkotik (PUSPEN), Bachok, Kelantan telah dipilih sebagai responden kajian. Data yang diperoleh dianalisis menggunakan ujian deskriptif. Hasil kajian mendapati sebanyak 39.5 peratus penghuni wanita mula terjebak dengan aktiviti penyalahgunaan dadah ketika berumur 15-20 tahun, kali pertama (79 peratus) ditangkap dan ditahan untuk menjalani proses pemulihan di bawah pengawasan PUSPEN dan majoritinya (54.6 peratus) berpengalaman mengambil dadah secara konsisten iaitu pada setiap hari. Majoriti (63 peratus) responden juga mengakui mendapatkan bekalan dadah daripada pihak pengedar. Analisa ke atas aspek penggunaan mendapati syabu (75.6 peratus) dan heroin (61.3 peratus) merupakan dadah paling popular yang digunakan oleh mereka. Hasil kajian seterusnya mendapati majoriti (60.5 peratus) penghuni dadah wanita menunjukkan tahap hubungan kekeluargaan yang sederhana. Hasil kajian memberi implikasi ke arah penambahbaikan proses rawatan dan pemulihan dadah di institusi khasnya untuk pengguna dadah wanita di Malaysia.
\end{abstract}

Kata kunci: Pengguna dadah; wanita; pengalaman penagihan dadah; hubungan kekeluargaan

(C) 2014 Penerbit UTM Press. All rights reserved. 


\subsection{PENGENALAN}

Wanita merupakan sebahagian daripada aset penting negara yang perlu dibangunkan secara optimum untuk membolehkan diri mereka menyumbang secara aktif dan berkesan kepada pembangunan negara dan masyarakat. Walaupun wanita Malaysia telah mencapai banyak kejayaan dalam arus pembangunan negara, namun masih terdapat pelbagai cabaran dan halangan yang boleh menjejaskan peranan dan status wanita untuk terus maju ke hadapan seperti keterlibatan mereka dengan aktiviti tidak sihat, iaitu terjebak dengan kegiatan penyalahgunaan dadah. Fenomena dan masalah dadah telah menjadi satu cabaran getir yang boleh menghalang kepada kemajuan kerjaya dan kecemerlangan jati diri wanita masa kini. Penglibatan wanita dengan kegiatan penyalahgunaan dadah bukan sahaja telah memberi kesan negatif kepada masalah sosial lain seperti keruntuhan moral, pelacuran dan kehancuran rumahtangga (Wilson \& Kelling, 1982) tetapi berupaya membawa kepada masalah kesihatan seperti jangkitan HIV/AIDS yang masih belum ada penawarnya. Berdasarkan laporan yang didedahkan oleh Kementerian Kesihatan Malaysia mendapati kes jangkitan HIV/AIDS dalam kalangan wanita meningkat daripada 737 orang pada tahun 2005 kepada 975 orang pada tahun 2006 (Kementerian Kesihatan Malaysia, 2007). Daripada aspek penyalahgunaan dadah pula, statistik menunjukkan sepanjang bulan Januari-November 2012, seramai 8,468 orang penagih telah dikesan berbanding tempoh yang sama tahun 2011, iaitu seramai 10,383 orang. Kesemua penagih yang dikesan terdiri daripada 4,948 orang (58.45 peratus) penagih baru. Manakala statistik yang dikeluarkan oleh Agensi Antidadah Kebangsaan (AADK) menunjukkan bilangan penagih berulang pula mencatatkan seramai 3,520 orang (41.57 peratus). Secara purata, seramai 15 orang penagih baru dan 11 penagih berulang telah dikesan pada setiap hari sepanjang JanuariNovember 2012 (AADK, 2013).

Daripada aspek pecahan mengikut jantina, statistik pada bulan Januari-November 2012 menunjukkan kes penagihan dadah melibatkan kaum wanita mencatatkan sebanyak 158 orang. Rekod yang didedahkan oleh AADK (2013) menunjukkan, bilangan penagih wanita yang tinggi dikesan di tiga buah negeri, iaitu di negeri Sarawak dan Perak, 24 kes, Johor (20 kes) dan Wilayah Persekutuan, Kuala Lumpur (19 kes). Walaupun kes penyalahgunaan dadah dalam kalangan wanita menunjukkan penurunan daripada aspek peratusannya, namun kesan keterlibatan wanita dengan aktiviti penyalahgunaan dadah perlu dipandang serius. Ini kerana wanita yang menggunakan dadah berisiko tinggi untuk berhadapan dengan stigma sosial masyarakat (Ayyagari, Boles, Johnson \& Kleber, 1999; Copeland, 1997) disebabkan oleh kegagalan dalam memenuhi aspirasi dan tuntutan hidup berkaitan dengan prinsip-prinsip akhlak wanita. Selain itu, wanita yang terlibat dengan aktiviti penyalahgunaan dadah juga dianggap oleh masyarakat sebagai kumpulan yang kurang berfungsi (Chatham, Hiller, Rowan-Szal, Joe \& Simpson, 1999) untuk memainkan peranan dalam penjagaan anak-anak dan pembentukan keluarga sejahtera (Davis, 1990; Sheridan, 1995). Menurut beberapa kajian yang telah dijalankan oleh sarjana barat mendapati bahawa wanita yang terlibat dengan masalah penyalahgunaan dadah berkecenderungan tinggi mengalami masalah yang berkaitan dengan psikologi (Alvarez, Olson, Jason, Davis, \& Ferrari, 2004; Chander \& McCaul, 2003; Gentilello et al., 2000; Mann, Hintz, \& Jung, 2004; Phillips, Carpenter \& Nunes, 2004; Zimmermann, Pin, Krenz, Bouchat, Favrat, Besson \& Zullino, 2004), seperti kemurungan, kebimbangan, gangguan bipolar afektif, fobia, gangguan psikoseksual dan gangguan akibat masalah yang berkaitan dengan tekanan selepas trauma (Brady,
Dansky, Sonne \& Salahuddin, 1998; Denier; Fornari, Kent, Kabo \& Goodman, 1991; Najavits, Weiss \& Shaw, 1997; Saxe \& Wolfe, 1999). Manakala kajian yang dijalankan oleh Fauziah, Mohamad, Chong \& Azmi (2012a) mendapati individu yang terlibat dengan dadah khasnya yang menggunakan dadah jenis heroin dan morfin berkecenderungan tinggi menunjukkan tingkah laku yang agresif.

Daripada aspek tanggungjawab menjaga anak pula, beberapa kajian barat mendapati wanita berkeluarga yang dikenal pasti terlibat dengan aktiviti penyalahgunaan dadah sering kali gagal menjalankan amanah dan tanggungjawab untuk menjaga anak-anak mereka (Poole \& Dell, 2005; Painter, RileyBuckley \& Whittington, 2000, Cox, Kelly \& Comiskey, 2008; Woods, 1999) sehingga menyebabkan anak-anak berasa terabai khasnya dalam memenuhi keperluan hidup mereka (Farrell, 2001). Keadaan ini secara tidak langsung boleh menjejaskan perkembangan psikososial anak-anak untuk membesar dengan sempurna. Menurut Keen, Oliver, Rowse \& Mathers (2000), kanak-kanak yang dikenal pasti mempunyai keluarga (ibu) yang terlibat dengan aktiviti penyalahgunaan dadah berhadapan dengan risiko mangsa penderaan sama ada secara fizikal mahupun mental. Manakala kajian yang dijalankan oleh UNODC (1995) mendapati, ibu bapa yang terlibat dengan aktiviti penyalahgunaan dadah terdedah dengan risiko besar dimana anak-anak berkemungkinan akan turut serta terjebak dan mencuba menggunakan dadah di rumah. Keadaan ini berlaku disebabkan oleh pengaruh tingkah laku negatif pengambilan dadah yang ditunjukkan oleh ahli keluarga khasnya ibu bapa yang merupakan tunggak utama keutuhan dan kesejahteraan sesebuah keluarga.

Dalam menentukan kejayaan pemulihan penagih dadah, institusi kekeluargaan merupakan institusi utama yang perlu memainkan peranan yang penting dalam kehidupan penagih khasnya yang sedang berada dalam proses pemulihan (Coyer, 2001; Velleman, Templeton \& Copello, 2005; Fauziah, Khadijah, Noremy, Norulhuda \& Lukman, 2012b; Vimpani 2005). Kajian menunjukkan hubungan keluarga yang kukuh membantu bekas penagih untuk meningkatkan kesejahteraan dan fungsi psikologi terhadap diri, mampu mengawal emosi dan membezakan perkara yang baik dan buruk (Copello, Velleman \& Templeton, 2005) dan seterusnya membantu menghindarkan diri mereka daripada terjebak semula dengan aktiviti penyalahgunaan dadah. Hubungan kekeluargaan yang baik juga mampu mengurangkan rasa rendah diri dalam kalangan bekas penagih yang sedang berjuang untuk kembali pulih daripada kesan dadah dan seterusnya membantu meningkatkan kejayaan pemulihan untuk bebas daripada pengaruh dadah (Butler \& Bauld, 2005; Blyth, Bamberg \& Toumbourou, 2000). Kajian yang dijalankan oleh Gilligan (1995), mendapati sokongan keluarga adalah penting untuk membina hubungan yang kukuh dalam kalangan ahli keluarga dan seterusnya membantu meningkatkan ketahanan diri ahli keluarga dalam menghadapi tekanan dan kesusahan dalam kehidupan. Manakala kajian yang dijalankan oleh Bahr, Maughan \& Marcos, (1998) mendapati ahli keluarga yang mempunyai ikatan dan hubungan kekeluargaan yang kuat mampu mencegah anak-anak daripada terlibat dengan gejala negatif seperti terjebak dengan masalah penyalahgunaan dadah. Sebaliknya hubungan yang renggang antara ahli keluarga akan menimbulkan konflik keluarga dan seterusnya menyebabkan ahli dalam sesebuah keluarga berisiko tinggi untuk terlibat dengan kegiatan penyalahgunaan dadah (Guo, Hill, Hawkins, Catalano \& Abbott, 2002; Buehler, 2006). Selain hubungan yang renggang, terdapat juga beberapa kajian yang mengaitkan faktor kurangnya komunikasi dan penerapan kaedah komunikasi yang tidak efektif dalam kalangan ahli keluarga sebagai faktor yang mendorong kepada berlakunya 
kecenderungan masalah sosial seperti keterlibatan ahli keluarga dengan aktiviti penyalahgunaan dadah (Musitu, Buelga, Lila \& Cava, 2000; Williams, McDermitt, Bertrand, \& Davis, 2003)

Memandangkan masalah penyalahgunaan dadah berupaya menjejaskan sahsiah dan memberi implikasi negatif terhadap institusi kekeluargaan khasnya dalam kalangan wanita yang terlibat dengan aktiviti penyalahgunaan dadah, maka usahausaha positif perlu digerakkan untuk memastikan wanita yang telah terlibat dengan aktiviti penyalahgunaan dadah dapat dipulihkan bagi mengembalikan peranan dan tanggungjawab mereka untuk memelihara kebajikan, perkembangan psikososial kanak-kanak dan keselamatan diri mereka. Manakala aspekaspek yang berkaitan dengan pengalaman penagihan serta hubungan kekeluargaan perlu dikenal pasti bagi tujuan membantu negara ke arah kejayaan kepulihan penagih dadah secara holistik. Hasil kajian diharap bukan sahaja dapat membantu menyediakan input pengalaman penyalahgunaan dadah wanita kepada pihak kaunselor pemulihan dadah namun ia juga mampu membantu institusi pemulihan dadah untuk memantapkan proses rawatan dan pemulihan dengan lebih menyeluruh khasnya kepada pengguna dadah wanita yang sedang menjalani program rawatan dan pemulihan dadah di Malaysia.

\subsection{OBJEKTIF KAJIAN}

Secara khusus, objektif kajian ini adalah untuk:

1. memerihalkan pengalaman penagihan dadah dalam kalangan wanita;

2. mengukur tahap hubungan kekeluargaan pengguna dadah wanita yang sedang menjalani program pemulihan di institusi.

\subsection{METOD KAJIAN}

Kajian ini berbentuk tinjauan dengan menggunakan reka bentuk tinjauan keratan-lintang (cross-sectional survey) secara kuantitatif dan dianalisis secara deskriptif. Reka bentuk keratanlintang menurut Malhotra, Sham, \& Crsip (1996) merupakan suatu kaedah yang melibatkan pengumpulan data terhadap satu jenis sampel daripada populasi yang dikaji secara sekali sahaja berdasarkan kepada atribut responden yang sedia ada. Manakala analisis deskriptif menurut Chua (2006) merupakan statistik yang digunakan untuk menghuraikan ciri-ciri variabel. Dalam kajian ini, analisis deskriptif digunakan untuk mengukur objektif kajian yang pertama iaitu memperihalkan pengalaman penagihan dadah dalam kalangan wanita dan objektif kedua kajian iaitu untuk mengukur tahap hubungan kekeluargaan pengguna dadah wanita yang sedang menjalani program pemulihan di institusi. Dari aspek instrumen, kajian ini telah menggunakan kaedah soal selidik untuk mendapatkan hasil kajian seperti berikut:

\subsection{Pengalaman Penagihan}

Pengalaman penagihan mengandungi soalan-soalan berkaitan dengan latar belakang dan pengalaman penyalahgunaan dadah dalam kalangan pengguna dadah wanita. Jenis item yang digunakan dalam bahagian ini adalah berbentuk item pilihan tunggal (single choice item) di mana responden diminta untuk membuat pilihan dengan cara memangkah (x) pada kotak yang disediakan berdasarkan pernyataan item yang sesuai dengan diri mereka. Soalan aneka pilihan (multiple-choice item) juga disediakan agar responden dapat memilih jawapan lebih daripada satu item yang dipersetujui. Misalnya soalan tentang jenis dadah yang pernah diambil dan sumber bekalan dadah yang diperolehi.

\subsection{Hubungan Kekeluargaan}

Hubungan kekeluargaan mengandungi 10 soalan yang berkaitan dengan hubungan kekeluargaan penghuni dadah wanita. Skala hubungan kekeluargaan yang pernah digunakan oleh Fauziah (2012c) dan memperoleh nilai kebolehpercayaan 0.614 telah digunakan untuk mengukur hubungan kekeluargaan dalam kalangan penghuni dadah wanita yang terlibat dalam kajian ini. Jenis item yang digunakan dalam skala ini adalah berbentuk Likert empat skala di mana pilihan-pilihannya disusun mengikut kesesuaian iaitu (1) sangat tidak setuju, (2) tidak setuju, (3) setuju dan (4) sangat setuju. Dalam kajian ini, nilai kebolehpercayaan yang diperolehi adalah 0.70. Tahap hubungan kekeluargaan dalam kalangan penghuni dadah wanita diukur berpandukan kepada jadual interpretasi skor min seperti Jadual 1 berikut:

Jadual 1 Jadual interpretasi skor min terhadap tahap hubungan kekeluargaan pengguna dadah wanita yang sedang menjalani program pemulihan di institusi

\begin{tabular}{ll}
\hline Skor min & Interpretasi skor min \\
\hline$<.20$ & Tahap rendah \\
$2.01-3.00$ & Tahap sederhana \\
$3.01-4.00$ & Tahap tinggi \\
\end{tabular}

Dalam kajian ini, populasi kajian merujuk kepada penghuni dadah wanita yang sedang mendapatkan khidmat rawatan dan pemulihan di Pusat Pemulihan Penagihan Narkotik (PUSPEN) Bachok, Kelantan. Berdasarkan statistik yang dikeluarkan oleh AADK pada bulan Januari-Julai 2011, populasi penagih dadah wanita yang berada di institusi adalah seramai 125 orang. Dalam kajian ini, persampelan rawak bertujuan telah digunakan untuk memilih ahli-ahli iaitu penagih-penagih dadah wanita untuk menjayakan kajian. Seramai 120 orang penghuni dadah wanita yang terdiri daripada pelbagai etnik telah dipilih untuk terlibat dalam menjayakan kajian.

\subsubsection{Proses Pengumpulan Borang Soal Selidik}

Sebelum pengumpulan data dimulakan, penyelidik pada awalnya telah memohon mendapatkan kebenaran secara bertulis daripada Ketua Pengarah AADK untuk menjalankan penyelidikan di PUSPEN, Bachok, Kelantan yang menempatkan wanita yang terlibat dengan aktiviti penyalahgunaan dadah. Setelah kelulusan bertulis diberikan oleh pihak AADK, penyelidik kemudiannya telah menghubungi dan membuat temujanji dengan Pengarah PUSPEN yang terlibat bagi menetapkan tarikh untuk kerja-kerja pengutipan data. Setelah sesuatu tarikh dipersetujui kedua-dua belah pihak, pengedaran borang soal selidik kemudiannya telah dijalankan secara rawak kepada penghuni wanita yang dikenal pasti mempunyai rekod penyalahgunaan dadah dan sedang menjalani program pemulihan di PUSPEN.

Sewaktu kerja-kerja pengutipan data dilakukan, penyelidik telah dibantu oleh Pegawai pemulihan dadah yang bertugas di penempatan pemulihan dadah wanita untuk menjalankan kerjakerja pengedaran dan pengutipan data. Kaunselor dan pegawaipegawai pemulihan yang terlibat terlebih dahulu diberikan 
penerangan dan taklimat ringkas berkaitan kaedah pengumpulan data oleh penyelidik. Seterusnya, Pegawai pemulihan dadah telah mengumpulkan penghuni dadah wanita yang terlibat dengan aktiviti penyalahgunaan dadah mengikut bilangan yang dikehendaki dan kemudiannya mengasingkan mereka kepada dua kumpulan seperti berikut:

\section{Penghuni wanita yang boleh membaca, dan}

2. Penghuni wanita yang tidak boleh membaca.

Tujuan pengasingan kumpulan berkenaan adalah untuk memudahkan proses bagi melengkapkan borang soal selidik dalam kalangan responden. Bagi penghuni wanita yang boleh membaca mereka telah menjawab setiap soalan pada borang soal selidik yang diedarkan secara sendirian dan diawasi oleh Pegawai pemulihan PUSPEN dan penyelidik sendiri. Manakala bagi kumpulan yang tidak tahu membaca, Pegawai pemulihan PUSPEN telah ditempatkan di dalam kumpulan mereka untuk membantu membacakan satu persatu soalan yang disediakan dengan tujuan memudahkan proses menjawab soalan oleh responden. Dalam masa yang sama, pengkaji juga bertindak mengawasi responden sewaktu mereka menjawab soal selidik bagi membolehkan mereka bertanya sekiranya terdapat soalansoalan yang kurang difahami.

Bagi mendapatkan jumlah borang soal selidik yang tepat, pengkaji telah memeriksa setiap helaian pada borang soal selidik sewaktu pengutipan borang soal selidik dijalankan. Ia bertujuan memastikan setiap responden mengisi borang soal selidik dengan sempurna dan lengkap. Sekiranya terdapat manamana borang soal selidik yang didapati tidak diisi dengan lengkap, pengkaji akan memulangkan semula kepada responden dan memastikan mereka menjawab soalan yang tercicir dengan bantuan daripada Pegawai pemulihan PUSPEN. Melalui pendekatan proses pengumpulan data ini, pengkaji telah berjaya mengumpulkan borang soal selidik yang tepat berdasarkan kepada bilangan sampel yang dikehendaki iaitu sebanyak 120 responden. Secara keseluruhannya, proses pengumpulan data telah berjalan dengan lancar berdasarkan faktor hubungan yang amat baik di antara Pegawai pemulihan PUSPEN dengan penyelidik.

\subsubsection{Penganalisaan Data}

Data kajian telah dianalisis dengan menggunakan 'Statistical Package for the Social Science for Windows' (SPSS for Windows). Statistik deskriptif digunakan untuk mencapai objektif kajian.

\section{Q.0 HASIL KAJIAN DAN PERBINCANGAN: PENGALAMAN PENGGUNAAN DADAH DALAM KALANGAN WANITA}

\subsection{Umur Mula Menagih Dadah}

Daripada aspek penelitian umur mula mengguna dadah, hasil kajian mendapati umur minimum responden mula terlibat dengan dadah adalah ketika berumur sembilan tahun, manakala umur maksimum adalah 41 tahun. Berdasarkan jadual tersebut, dapat dirumuskan bahawa 39.5 peratus pengguna dadah wanita yang dikaji mula terlibat dengan dadah ketika berumur di peringkat awal remaja iaitu dalam lingkungan 15-20 tahun. Manakala selebihnya mula berjinak-jinak menggunakan dadah sejak berumur dalam lingkungan 9-14 tahun iaitu seramai 18 orang (15.1 peratus), 21-26 tahun seramai 34 orang (28.6 peratus), 27-32 tahun, seramai sembilan orang, 33-38 tahun seramai lapan orang (6.7 peratus) dan 39-41 tahun seramai tiga orang ( 2.5 peratus)

\subsection{Tempoh Pengalaman Penagihan Dadah}

Analisis terhadap aspek tempoh pengalaman penagihan dadah mendapati, tempoh pengalaman penagihan antara 1-6 tahun merupakan tempoh masa yang paling tinggi dicatatkan di kalangan penghuni dadah wanita iaitu seramai 61 orang (50.4 peratus). Manakala seramai 26 orang (21.8 peratus) orang responden telah menagih dalam tempoh 7-12 tahun, sementara selebihnya iaitu 14 orang (11.8.0 peratus) responden telah menagih dalam tempoh 13-19 tahun. Hasil kajian hanya menunjukkan seramai 11 orang (9.2 peratus) telah menagih dadah dalam tempoh 20-26 tahun dan tujuh orang (5.9 peratus) telah dikenal pasti menagih dadah dalam tempoh yang agak lama iaitu 27-33 tahun. Tempoh penagihan dadah yang lama ini sering dikaitkan dengan relaps di mana penagih agak sukar untuk dipulihkan sepenuhnya daripada kesan dadah dan berisiko tinggi untuk berhadapan dengan keadaan relaps (Fauziah \& Naresh, 2009). Menurut Saunders \& Allsop (1987), penagihan relaps didefinisikan sebagai 'kembali ke tahap sebelum rawatan'. Manakala menurut Mahmood (1996), penagihan relaps bermaksud penggunaan, pengambilan atau penyalahgunaan bahan psikoaktif selepas seseorang itu telah selesai menjalani rawatan dan pemulihan penagihan dadah dari segi pergantungan fizikal dan psikologikal terhadap dadah.

\subsection{Kekerapan Masuk Ke Pusat Pemulihan Dadah}

Berdasarkan tinjauan terhadap aspek kekerapan masuk ke pusat pemulihan dadah pula, hasil kajian mendapati seramai 95 orang (79 peratus) responden mengakui bahawa mereka tidak pernah menerima rawatan pemulihan dadah sebelum ini (pertama kali). Manakala seramai 12 orang (10.1 peratus) lagi telah menerima khidmat rawatan pemulihan sebanyak dua kali, lima orang (4.2 peratus) sebanyak tiga kali, empat orang (3.4 peratus) sebanyak empat kali dan seorang (0.8 peratus) sebanyak tujuh kali. Secara rumusannya, bilangan minimum kekerapan masuk responden ke pusat pemulihan dadah adalah pertama kali sementara bilangan maksimum untuk mendapatkan khidmat pemulihan dadah adalah sebanyak tujuh kali.

\subsection{Kekerapan Mengambil Dadah Dalam Tempoh Seminggu}

Ditinjau daripada aspek kekerapan mengambil dadah dalam tempoh seminggu, maklumat kajian mendapati sejumlah 66 orang (54.6 peratus) penghuni dadah wanita telah mengambil dadah pada setiap hari dalam tempoh seminggu. Manakala penggunaan dadah melebihi dua kali sehari dalam tempoh yang sama mencatatkan sejumlah 14 orang (11.8 peratus) dan melebihi dua kali dalam sehari sejumlah 22 orang (18.5 peratus). Selebihnya iaitu 8 (6.7 peratus) orang lagi telah dikenal pasti menggunakan dadah selang sehari dalam tempoh seminggu. Keadaan ini menunjukkan bahawa majoriti daripada responden yang terlibat dalam kajian ini merupakan mereka yang mempunyai tahap kebergantungan kepada dadah yang cukup tinggi sebelum memasuki pusat pemulihan. Oleh itu, tugas kaunselor pemulihan dadah dilihat berhadapan dengan cabaran dari aspek pemulihan untuk memastikan mereka yang dirawat sepanjang tempoh 2 tahun di PUSPEN, benar-benar pulih dan berjaya bebas daripada pengaruh dadah. Jadual 2 menunjukkan secara ringkas pengalaman penggunaan dadah dalam kalangan wanita yang sedang mendapatkan rawatan dan pemulihan di PUSPEN. 
Jadual 2 Pengalaman penagihan dan penggunaan dadah dalam kalangan wanita

\begin{tabular}{|c|c|c|}
\hline Pengalaman Penagihan & Bil. $(n=120)$ & Peratus \\
\hline \multicolumn{3}{|l|}{ Umur Mula Menagih (Tahun) } \\
\hline $9-14$ & 18 & 15.1 \\
\hline $15-20$ & 48 & 39.5 \\
\hline $21-26$ & 34 & 28.6 \\
\hline $27-32$ & 9 & 7.6 \\
\hline $33-38$ & 8 & 6.7 \\
\hline $39-41$ & 3 & 2.5 \\
\hline \multicolumn{3}{|l|}{ Tempoh Penagihan (Tahun) } \\
\hline $1-6$ & 61 & 50.4 \\
\hline $7-12$ & 26 & 21.8 \\
\hline $13-19$ & 14 & 11.8 \\
\hline $20-26$ & 11 & 9.2 \\
\hline $27-33$ & 7 & 5.9 \\
\hline \multicolumn{3}{|l|}{$\begin{array}{l}\text { Kekerapan Masuk Ke Pusat } \\
\text { Pemulihan Dadah (Kali) }\end{array}$} \\
\hline 1 & 95 & 79.0 \\
\hline 2 & 12 & 10.1 \\
\hline 3 & 5 & 4.2 \\
\hline 4 & 4 & 3.4 \\
\hline 5 & 3 & 2.5 \\
\hline 7 & 1 & .8 \\
\hline \multicolumn{3}{|l|}{$\begin{array}{l}\text { Kekerapan Mengambil Dadah } \\
\text { Seminggu }\end{array}$} \\
\hline Tiap-Tiap Hari & 66 & 54.6 \\
\hline Dua Kali Dalam Sehari & 14 & 11.8 \\
\hline Selang Sehari & 8 & 6.7 \\
\hline $\begin{array}{l}\text { Melebihi dua kali dalam } \\
\text { sehari }\end{array}$ & 22 & 18.5 \\
\hline Lain-Lain & 10 & 8.4 \\
\hline
\end{tabular}

\subsection{Sumber Bekalan Dadah}

Dari aspek sumber bekalan dadah diperoleh, kajian mendapati majoriti responden (63 peratus) mengaku bahawa sepanjang penagihan, mereka telah mendapatkan bekalan dadah daripada pihak pengedar (Jadual 3). Manakala seramai 55 orang (46.2 peratus) lagi mengaku telah memperoleh bekalan dadah daripada rakan, 29 orang (24.4 peratus) telah mendapatkan dadah daripada penjual runcit (pusher) dan selebihnya iaitu 5 orang (4.2 peratus) lagi mendapatkan bekalan dadah daripada sumber-sumber lain. Keadaan ini memberi gambaran bahawa terdapat pelbagai cara dan kaedah yang digunakan oleh pengguna dadah wanita untuk memperoleh sumber bekalan dadah sehingga menjejaskan kesihatan dan pembentukan jati diri mereka sebagai seorang insan yang berguna. Di Malaysia, walaupun Akta Dadah Berbahaya 1952, memperuntukkan hukuman mati kepada pengedar dadah (Laporan Dadah Malaysia, 2002), namun perundangan ini dilihat sedikit pun tidak menakutkan pengedar dan penagih. Secara umumnya, ketegasan undang-undang dan prospek mati ditali gantung masih belum memadai dan dipandang ringan oleh pengedar dan penagih di negara ini.

Jadual 3 Peratusan sumber bekalan dadah diperoleh

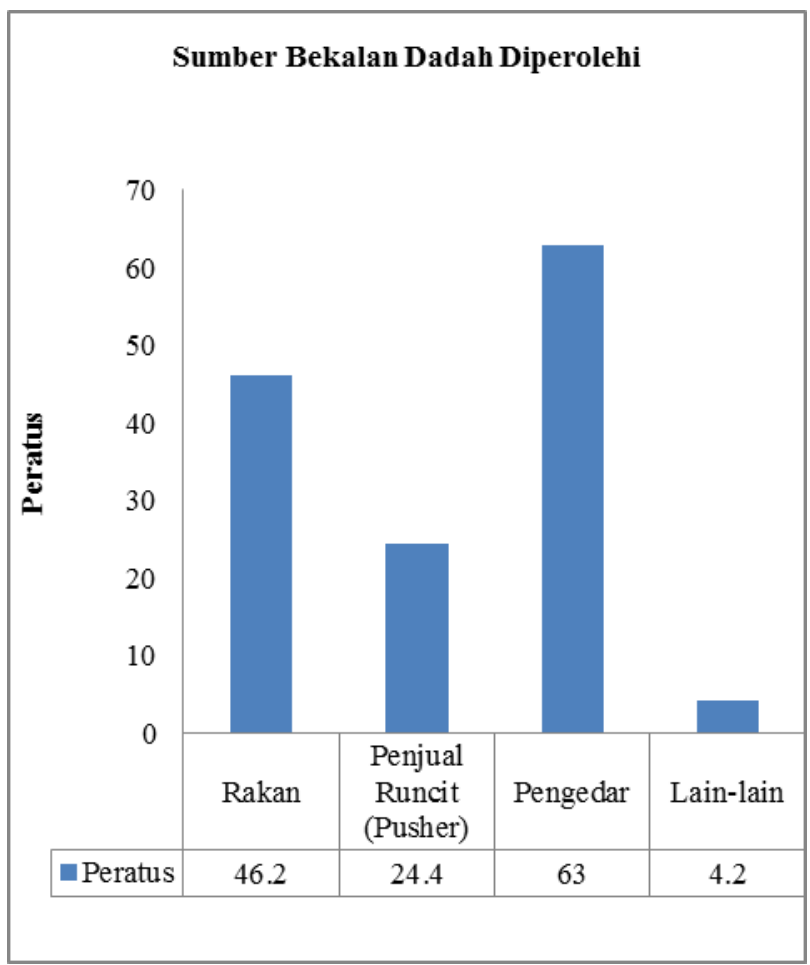

\subsection{Jenis-Jenis Dadah Yang Digunakan}

Secara umumnya adalah dijangkakan bahawa pengguna dadah wanita yang terlibat dalam kajian ini merupakan mereka yang telah terjerumus ke alam penagihan yang serius dan telah mengambil pelbagai jenis dadah yang terlarang. Keadaan ini disahkan oleh maklumat yang diperoleh hasil daripada kajian yang dijalankan (Jadual 4). Daripada jumlah keseluruhan mereka itu, seramai 90 orang atau 75.6 peratus membuat pendedahan bahawa mereka telah menggunakan dadah jenis syabu. Kajian ini mendedahkan dadah jenis syabu merupakan dadah popular yang diambil oleh kebanyakan responden yang terlibat dalam kajian ini. Manakala selebihnya iaitu seramai 61.3 peratus responden telah menggunakan dadah jenis heroin, ganja, 36.1 peratus, amphetamine 23.5 peratus, morfin, 15.1 peratus dan candu 4.2 peratus. Lain-lain jenis dadah juga turut digunakan oleh responden seperti kokain, dan inhalan (gam) dengan catatan sebanyak 10.1 peratus daripada 120 orang penghuni wanita yang terlibat dalam kajian ini. Hasil kajian ini berbeza dengan hasil kajian yang dijalankan oleh Asmawati \& Fatimah (2005), yang mendapati tren penggunaan dadah jenis heroin merupakan dadah popular yang digunakan oleh pengguna dadah wanita dalam tempoh lapan tahun yang lalu. Manakala kajian yang dijalankan oleh Fauziah, Salina \& Nur Saadah (2012d) terhadap 200 orang remaja lelaki yang sedang menjalani program pemulihan dadah di institusi mendapati dadah jenis kokain merupakan dadah popular yang pernah diambil dalam kalangan majoriti mereka.

Secara keseluruhannya, berdasarkan pengalaman penagihan dadah dalam kalangan wanita, hasil kajian juga mendapati seramai 39.5 peratus pengguna dadah wanita yang 
dikaji menunjukkan mereka mula terjebak dengan aktiviti penyalahgunaan dadah ketika remaja iaitu berumur dalam lingkungan 15-20 tahun, kali pertama (79 peratus) ditangkap dan ditahan untuk menjalani proses pemulihan di bawah pengawasan Pusat Pemulihan Penagihan Narkotik (PUSPEN) dan majoriti daripada mereka (54.6 peratus) berpengalaman mengambil dadah secara konsisten sewaktu sedang menagih iaitu pada tiap-tiap hari. Majoriti (63 peratus), mereka juga mengakui telah mendapatkan bekalan dadah daripada pihak pengedar dadah dan 46.2 peratus mengakui mendapatkan dadah daripada rakan. Daripada aspek penggunaan jenis dadah, syabu (75.6 peratus), heroin (61.3 peratus) serta ganja (36.1 peratus) merupakan antara jenis dadah popular yang digunakan oleh pengguna dadah wanita yang terlibat dengan kajian ini.

Jadual 4 Peratusan jenis dadah pernah digunakan oleh penghuni wanita

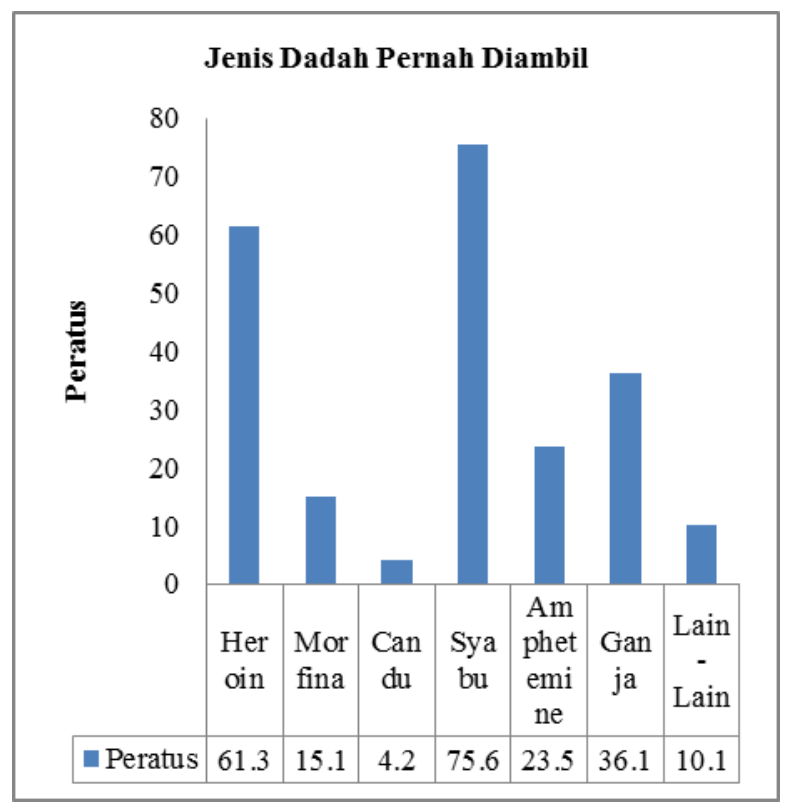

15.0 TAHAP HUBUNGAN KEKELUARGAAN DALAM KALANGAN PENGGUNA DADAH WANITA

Jadual 5 menunjukkan tahap hubungan kekeluargaan dalam kalangan penghuni dadah wanita. Hasil kajian yang dijalankan mendapati, majoriti pengguna dadah wanita yang terlibat dalam kajian ini menunjukkan tahap hubungan kekeluargaan yang sederhana (60 peratus) ke tahap yang tinggi (37 peratus). Hasil kajian ini memberi gambaran bahawa pengguna dadah wanita yang terlibat dengan kajian ini masih bernasib baik kerana keluarga mereka kebanyakan masih menunjukkan perhatian dan mengambil tahu tentang keadaan mereka. Hanya 2.5 peratus dalam kalangan pengguna dadah wanita yang dikaji merekodkan hubungan kekeluargaan yang rendah.
Jadual 5 Tahap hubungan kekeluargaan penghuni dadah wanita

\begin{tabular}{ccc}
\hline $\begin{array}{c}\text { Hubungan } \\
\text { Keluarga }\end{array}$ & $\mathbf{N = 1 2 0}$ & Peratus (\%) \\
\hline Rendah (<.20) & 3 & 2.5 \\
$\begin{array}{c}\text { Sederhana (2.01- } \\
\text { 3.00) }\end{array}$ & 72 & 60.5 \\
Tinggi (3.01-4.00) & 44 & 37.0 \\
JUMLAH & $\mathbf{1 2 0}$ & $\mathbf{1 0 0}$ \\
\hline
\end{tabular}

Hubungan kekeluargaan yang sederhana ini menunjukkan bahawa keluarga bukan merupakan antara faktor dan punca utama mereka terlibat dengan aktiviti penyalahgunaan dadah. Hal ini dapat diterjemahkan melalui hasil dapatan kajian yang mendapati bahawa seramai 56.3 peratus pengguna dadah wanita yang terlibat dalam kajian ini mengakui bahawa masalah keluarga bukan antara faktor penyebab mereka terlibat dengan aktiviti penyalahgunaan dadah (item 9) (Jadual 6). Hasil kajian ini dilihat selari dengan kajian yang dijalankan oleh Fauziah et al., (2012b) yang mendapati bahawa sebanyak 64 peratus penagih dadah remaja lelaki yang sedang mendapatkan khidmat rawatan dan pemulihan di institusi menyatakan pandangan bahawa mereka bersetuju dan amat bersetuju dengan pernyataan yang menyatakan bahawa keluarga bukan merupakan faktor yang menyebabkan mereka terjebak dengan kegiatan penyalahgunaan dadah.

Walaupun hasil kajian menunjukkan majoriti (62.2 peratus) pengguna dadah wanita mengakui bahawa mereka mempunyai pandangan yang berbeza dengan keluarga tentang kehendak dan kemahuan mereka (item 7), namun dapatan kajian secara keseluruhannya menunjukkan bahawa keluarga merupakan pihak yang memberikan sokongan yang tinggi kepada mereka untuk pulih daripada kesan negatif dadah. Hal ini dapat digambarkan melalui hasil kajian yang mendapati seramai 81.5 peratus pengguna dadah wanita bersetuju dan sangat bersetuju menyatakan bahawa mereka amat bergantung pada keluarga untuk mendapatkan sokongan dari segi emosi dan juga semangat (item3), 77.3 peratus daripada mereka pula mengakui bahawa keluarga merupakan tempat untuk mereka mengadu semasa berada dalam keadaan kesusahan dan kesedihan (item 4). Sesungguhnya, sokongan keluarga berterusan yang tinggi amat diperlukan oleh bekas pengguna dadah bukan sahaja ketika diperingkat awal proses rawatan dan pemulihan, tetapi sepanjang proses pemulihan dijalankan. Sokongan keluarga yang lemah dan tidak menggalakkan berisiko menjadi penyebab kepada keadaan yang dinamakan sebagai relaps (Brown, dll., 1995; Miller, dll., 1999; Moos \& King, 1997) dan seterusnya menyukarkan bekas penagih untuk membina kerjaya bagi menampung kehidupan bekeluarga (Fauziah, Mustaffa, Lukman, Khadijah, Norulhuda, Salina \& Nasrudin, 2011). Justeru itu, keluarga adalah disaran untuk sentiasa bersikap tabah dan tidak pernah jemu untuk memberikan sokongan kepada bekas penagih untuk pulih dan bebas daripada pengaruh dadah. 
Jadual 6 Taburan peratusan hubungan kekeluargaan penghuni dadah wanita

\begin{tabular}{|c|c|c|c|c|c|c|}
\hline \multirow[t]{2}{*}{ No } & \multirow[t]{2}{*}{ Item } & $\begin{array}{c}\text { Sangat } \\
\text { Tidak } \\
\text { Setuju }\end{array}$ & $\begin{array}{l}\text { Tidak } \\
\text { Setuju }\end{array}$ & Setuju & $\begin{array}{l}\text { Sangat } \\
\text { Setuju }\end{array}$ & \multirow[t]{2}{*}{ Min } \\
\hline & & $\mathrm{P}(\%)$ & $\mathrm{P}(\%)$ & $\mathrm{P}(\%)$ & $\mathrm{P}(\%)$ & \\
\hline 1 & $\begin{array}{l}\text { Keluarga saya memberikan sokongan moral yang saya } \\
\text { perlukan untuk berhenti menagih. }\end{array}$ & 0.8 & 9.2 & 37.0 & 52.9 & 3.42 \\
\hline 2 & $\begin{array}{l}\text { Keluarga selalu mengingatkan saya bahawa dadah itu } \\
\text { bahaya dan perlu elak daripada terjebak. }\end{array}$ & 1.7 & 11.8 & 38.7 & 47.9 & 3.33 \\
\hline 3 & $\begin{array}{l}\text { Saya bergantung kepada keluarga untuk mendapatkan } \\
\text { sokongan emosi/semangat. }\end{array}$ & 2.5 & 16.0 & 41.2 & 40.3 & 3.19 \\
\hline 4 & $\begin{array}{l}\text { Keluarga menjadi tempat saya mengadu semasa berasa } \\
\text { sedih. }\end{array}$ & 2.5 & 20.2 & 47.9 & 29.4 & 3.04 \\
\hline 5 & $\begin{array}{l}\text { Saya mempunyai hubungan yang rapat dengan ahli } \\
\text { keluarga saya. }\end{array}$ & 5.9 & 16.8 & 46.2 & 31.1 & 3.03 \\
\hline 6 & $\begin{array}{l}\text { Keluarga saya boleh mendengar dan menyelesaikan } \\
\text { masalah saya. }\end{array}$ & 5.9 & 26.1 & 48.7 & 19.3 & 2.82 \\
\hline 7 & $\begin{array}{l}\text { Keluarga saya mempunyai pandangan yang berbeza } \\
\text { dengan diri dan kehendak saya. }\end{array}$ & 2.5 & 35.3 & 45.4 & 16.8 & 2.76 \\
\hline 8 & $\begin{array}{l}\text { Ahli keluarga sering melawat saya semasa di } \\
\text { PUSPEN. }\end{array}$ & 7.6 & 41.2 & 34.5 & 16.8 & 2.61 \\
\hline 9 & $\begin{array}{l}\text { Masalah keluarga adalah penyebab saya menagih } \\
\text { dadah. }\end{array}$ & 14.3 & 42.0 & 33.6 & 10.1 & 2.39 \\
\hline 10 & $\begin{array}{l}\text { Ibu bapa saya sering sibuk, tidak mempedulikan dan } \\
\text { tiada masa untuk bersama-sama saya. }\end{array}$ & 16.8 & 49.6 & 26.1 & 7.6 & 2.24 \\
\hline
\end{tabular}

Hasil kajian ini seterusnya mendapati ahli keluarga pengguna dadah wanita kebanyakannya (51.3 peratus) telah meluangkan masa untuk datang melawat mereka sepanjang menjalani program pemulihan dadah di bawah kendalian pihak PUSPEN (item 8). Keadaan ini menunjukkan wujudnya hubungan yang rapat antara penghuni dadah wanita dengan keluarga mereka. Hal ini dapat diterjemahkan melalui pengakuan hampir sebilangan besar (77.3 peratus) pengguna dadah wanita yang mengakui bahawa mereka mempunyai hubungan yang amat rapat dengan ahli keluarga mereka (item 5). Kebanyakan mereka (66.4 peratus) juga menolak dan tidak bersetuju dengan pernyataan yang mengatakan bahawa ibu bapa sering sibuk dan tiada masa untuk bersama-sama mereka (item10). Dapatan kajian ini memberi gambaran bahawa sokongan baik yang ditunjukkan oleh ahli keluarga kepada penghuni dadah wanita mampu memberi impak yang positif terhadap proses pemulihan penagih, membantu meningkatkan kesejahteraan dan fungsi psikologi terhadap diri dan seterusnya membantu mengurangkan keadaan berisiko tinggi relaps dalam kalangan mereka (Copello et al., 2005). Selain itu, hubungan kekeluargaan yang baik juga berupaya mengurangkan rasa rendah diri dalam kalangan bekas penagih yang sedang berjuang untuk kembali pulih daripada kesan dadah dan seterusnya mampu meningkatkan kejayaan pemulihan untuk bebas daripada pengaruh dadah (Butler \& Bauld, 2005; Blyth et al., 2000). Seharusnya kejayaan pemulihan dadah yang berterusan bukan sahaja terletak kepada peranan dan sokongan yang ditunjukkan oleh ahli keluarga terhadap penagih, namun kejayaan pemulihan yang lebih besar adalah terletak kepada diri bekas penagih itu sendiri untuk pulih dan benar-benar bebas daripada pengaruh dadah.
Secara keseluruhannya, hasil kajian ini dilihat bertentangan dengan hasil kajian yang dijalankan oleh kebanyakan pengkaji terdahulu yang sering mengaitkan ikatan kekeluargaan yang longgar, berpecah belah, tidak rapat, mempunyai konflik dan krisis sebagai antara faktor penyebab membawa kepada berlakunya kepincangan dan keterlibatan anak-anak dengan gejala sosial yang tidak sihat seperti penyalahgunaan dadah (Lerner \& Galambos, 1998; Mackay, 2003; Hawkins,1992; Friedman \& Beschner, 1982; Harunnaja, 2003; Rohayati, 2004; Hoffman \& Johnson, 1998; Brook, Whiteman \& Gordon, 2000). Hasil dapatan yang berbeza juga mungkin disebabkan oleh perbezaan budaya, trend dan perubahan gaya hidup masa kini yang terdedah dengan pelbagai cabaran selaras dengan arus pesat pembangunan negara yang kian mencabar. Walau bagaimanapun, dapatan kajian ini telah memberi petunjuk dan ingatan yang amat bermakna khasnya kepada institusi kekeluargaan masa kini. Ini bermakna keluarga yang sejahtera, jauh dari kepincangan dan konflik rumahtangga tidak akan terlepas daripada menerima ketentuan bahawa anak-anak mereka juga berpotensi untuk terlibat dengan aktiviti yang boleh terpesong dari segi nilai dan akhlaknya dalam mengatur kehidupan disebabkan keterlibatan dengan aktiviti yang tidak sihat seperti penyalahgunaan dadah. Oleh itu, peranan keluarga perlu diperkukuhkan dan institusi kekeluargaan perlu sentiasa mengambil berat tentang keperluan serta kehendak anak masing-masing bagi memastikan kehidupan kekeluargaan dapat diteruskan dengan keadaan yang sempurna dan seterusnya ahli keluarga dapat menyumbang khidmat bakti kepada agama, bangsa dan juga negara tercinta. Hubungan antara ahli dalam keluarga yang positif bukan sahaja mampu mewujudkan keadaan yang harmoni malah mampu mencegah berlakunya kecenderungan tingkah laku negatif (Kumpfer, Alvarado \& 
Whiteside, 2003; Buelga \& Pons, 2004). Bagi tujuan membantu meningkatkan kefungsian keluarga khasnya dalam kalangan ibubapa yang mempunyai rekod keterlibatan ahli keluarga dengan masalah penyalahgunaan dadah, program pendidikan keluarga yang menawarkan pengetahuan dan kemahiran keibubapaan oleh agensi yang berkepentingan adalah diperlukan untuk membantu meningkatkan kesedaran, pembinaan emosi positif dan pembangunan sahsiah anak-anak. Program pendidikan keluarga ini juga perlu menekankan tentang hal-hal yang berkaitan dengan kaedah untuk membantu anak-anak yang terlibat dengan dadah dengan memberikan penekanan penting terhadap aspek pendidikan yang berkaitan dengan pembinaan potensi dan kemahiran diri, meningkatkan kesedaran anak-anak untuk terus menghindari diri daripada bahaya dadah dan keperluan perkongsian maklumat dan pandangan apabila anak mereka berhadapan dengan cabaran dan keadaan kesukaran dalam menjalani kehidupan. Menurut kajian yang dijalankan oleh Lila \& Gracia (2005), sikap ambil peduli, pengawasan secara konsisten tentang aktiviti anak-anak dan kepentingan memberikan pendidikan yang sempurna (McIntosh, MacDonald \& McKeganey, 2005) mampu membantu menghindarkan diri anak-anak daripada terjebak dengan tingkah laku berisiko. Manakala sokongan sosial keluarga yang berterusan juga dilihat mampu mengekalkan kepulihan jangka panjang dalam kalangan bekas penagih bagi meneruskan kehidupan baru yang lebih bermakna (Gruber \& Fleetwood, 2004).

\subsection{KESIMPULAN}

Kajian terhadap pengalaman penagihan dadah dalam kalangan wanita dan pengenalpastian terhadap tahap hubungan kekeluargaan telah memberi implikasi positif bukan sahaja kepada kaunselor pemulihan dadah, malah memberi input penting kepada institusi pemulihan dadah di Malaysia yang sentiasa berhadapan dengan cabaran dalam proses pemulihan penagih. Pelbagai latar belakang pengguna dadah juga telah memberikan halangan kepada institusi pemulihan untuk menerapkan modul rawatan yang sama kepada semua klien di bawah pengawasan mereka. Namun, hasil kajian terhadap pengalaman penyalahgunaan dadah dalam kalangan wanita ini dilihat mampu memberikan input baru kepada institusi pemulihan untuk merangka dan melakukan penambahbaikan terhadap modul rawatan pemulihan kepada pengguna dadah wanita. Hasil kajian ini juga diharap mampu memberi kesedaran khusus kepada institusi kekeluargaan tentang peranan penting mereka untuk bersama-sama membantu pihak AADK dalam membanteras dan memulihkan penagih dadah khasnya dalam kalangan wanita di Malaysia. Sokongan sosial yang berterusan dalam kalangan keluarga mampu membantu proses pemulihan dalam kalangan penagih untuk terus mengamalkan gaya hidup sihat, bebas daripada pengaruh dadah dan membantu mengurangkan kadar residivis dalam kalangan penagih dadah di Malaysia.

\section{Penghargaan}

Kajian ini telah mendapat sokongan pembiayaan geran daripada dana Insentif Penyelidik Muda UKM-DIPM-086-2011, Universiti Kebangsaan Malaysia. Penghargaan juga ditujukan kepada Agensi AntiDadah Kebangsaan (AADK), Fakulti Sains Sosial dan Kemanusiaan dan semua pihak yang terlibat dalam menjayakan kajian ini.
Rujukan

Agensi Anti Dadah Kebangsaan. 2013. Laman Web Statistik Penyalahgunaan Dadah http://www.adk.gov.my/utama.html. Diakses pada 2 Januari 2013

Alvarez, J., Olson, B. D, Jason, L. A., Davis, M. I., \& Ferrari, J. R. 2004 Heterogeneity among Latinas and Latinos Entering Substance Abuse Treatment: Findings from a National Database. Journal of Substance Abuse Treatment. 26: 277-284.

Asmawati Desa \& Fatimah Yusooff. 2005. Profil Penagih Dadah Golongan Belia Wanita: Satu Kajian Premilari. Prosiding Seminar Penyelidikan Pembangunan Generasi Muda: Realiti Generasi Muda Melangkah Ke hadapan. Anjuran FSSK, UKM dan Institut Penyelidikan Pembangunan Belia Malaysia: Kementerian Belia dan Sukan Malaysia

Ayyagari, S., Boles, S., Johnson, P \& Kleber, H. 1999. Difficulties in Recruiting Pregnant Substance Abusing Women into Treatment: Problems Encountered during the Cocaine Alternative Treatment Study. Abstract Book/Association for Health Services Research. 16 80-81.

Bahr, S. J., Maughan, S. L., Marcos, A. C \& Li, B. 1998. Family, Religiosity, and the Risk of Adolescent Drug Use. Journal of Marriage and Family. 60: 979-992. doi: 10.1177/002204260803800305.

Blyth, A., Bamberg, J., Toumbourou, J. 2000. Behaviour Exchange Systems Training: A Program for Parents Stressed by Adolescent Substance Abuse. Australian Council for Educational Research: Camberwell, Australia.

Brady, K. T., Dansky, B. S., Sonne, S. C., \& Saladin, M. E. 1998. Posttraumatic Stress Disorder and Cocaine Dependence: Order of Onset. American Journal on Addictions. 7: 128-135. doi: 10.1111/j.1521-0391.1998.tb00327.x.

Brown, S. A., Vik, P. W., Patterson, T. L., Grant, I., \& Schuckit, M. A. 1995. Stress, Vulnerability and Adult Alcohol Relapse. Journal of Studies on Alcohol. 56(5): 538-545. doi: 10.1037/0022-3514.78.5.979.

Buehler, C. 2006. Parents and Peers in Relation to Early Adolescent Problem Behavior. Journal of Marriage and Family. 68(1): 109-124. doi: 10.1111/j.1741-3737.2006.00237.x.

Buelga, S., \& Musitu, G. 2004. Famille t Adolescence: Prévention de conduite à risque. [Family and Adolescence: Prevention of risk behaviours]. Plenary conference presented at the XIX symposium Scientific Psychology of French Language. Current adolescence. Caen: Lower Normandy.

Butler, R., Bauld, L. 2005. The Parents' Experience: Coping with Drug Use in the Family. Drugs: Education, Prevention and Policy. 12(1)

Chua Yan Piaw. 2006. Kaedah dan Statistik Penyelidikan: Kaedah Pendidikan. Kuala Lumpur: McGraw Hill.

Chatham, L. R., Hiller, M. L., Rowan-Szal, G. A., Joe, G. W., \& Simpson, D. D. 1999. Gender Differences at Admission and Follow-up in a Sample of Methadone Maintenance Clients. Substance Use \& Misuse. 34(8): 1137-1165. doi:10.3109/10826089909039401.

Chander, G., \& McCaul, M. E. 2003. Co-occurring Psychiatric Disorders in Women with Addictions. Obstetrics and Gynecology Clinics of North America. 30(3): 469-481.

Cox, G., Kelly, P. \& Comiskey, C. 2008. ROSIE Findings 5: Gender Similarities and Differences in Outcomes at 1-year. Dublin: National Advisory Committee on Drugs. http://www.nacd.ie/publications/Rosie_5_web.pdf.

Coyer, S. M. 2001. Mothers Recovering from Cocaine Addiction: Factors Affecting Parenting Skills. Journal of Obstetric, Gynecologic, and Neonatal Nursing. 30(1): 71-79.

Copeland, J. 1997. A Qualitative Study of Barriers to Formal Treatment Among Women Who Self-managed Change in Addictive Behaviours. Journal of Substance Abuse Treatment. 14(2): 183-190. doi.org/10.1016/S0740-5472(96)00108-0.

Copello, A., Velleman, R., Templeton, L. 2005. Family Interventions in the Treatment of Alcohol and Drug Problems. Drug and Alcohol Review. 24(4): 369-85. doi/10.1080/09595230500302356/pdf.

Davis, S. K. 1990. Chemical Dependency in Women: A Description of Its Effects and Outcome on Adequate Parenting. Journal of Substance Abuse Treatment. 7(4): 225-232. doi: 10.1016/0740-5472(90)90045-R.

Denier, C. A., Thevos, A. K., Latham, P. K., \& Randall, C. L. 1991. Psychosocial and Psychopathology Differences in Hospitalized Male and Female Cocaine Abusers: A Retrospective Chart Review. Addictive Behaviors. 16(6): 489-496. doi:10.1016/03064603(91)90056-N.

Fauziah Ibrahim \& Naresh. 2009. Factor Effecting Drug Relapse in Malaysia: An Empirical Evidence. Asian Social Science. 5(12): 37-44.

Fauziah Ibrahim, Mustaffa Omar, Lukman Mohamad, Khadijah Alavi, Norulhuda Sarnon, Salina Nen \& Nasrudin Subhi. 2011. Employment 
Barriers Against People with Drug Use Histories. Pertanika Journal of Social Sciences and Humanities. 19(S): 109-114. ISSN:01287702.

Fauziah Ibrahim, Mohamad Suhaimi Mohamad, Chong Tsuey Suey \& Azmi Abd Manaf. 2012a. Substance Abuse and Aggressive Behavior among Adolescents. Asian Social Science. 8(9): $92-97$. doi:10.5539/ass.v8n9p92.

Fauziah Ibrahim, Khadijah Alavi, Noremy Md Akhir, Norulhuda Sarnon \& Lukman Mohamad. 2012b. The role of family towards current adolescence challenges: Drug prevention and living without drugs. The Social Science. 7(2): 341-345. doi: 10.3923/sscience.2012. 341.345 .

Fauziah Ibrahim. 2012c. Remaja dan penyalahgunaan Dadah: Input untuk memperkasakan Jatidiri Remaja Malaysia Bebas Dadah. 2012c Laporan Penyelidikan Akhir Dana Penyelidik Muda. Bangi: UKM.

Fauziah Ibrahim, Salina Nen \& Nur Saadah Mohamad Aun. 2012d. A Profile of Male Adolescents Background and Experiences in Substance Abuse. Asian Social Sciences. 8(12):109-119. doi:10.5539/ass.v8n12p109.

Farrell, E. 2001. Women, Children \& Drug Use. In Pike, B. (Ed) A Collection of Papers on Drug Issues in Ireland. Dublin: Drug Misuse Research Division, The Health Research Board.

Friedman, A. S. \& Beschner, J. 1982. Families of Adolescent Drug Abuse Clients. Treatment Research Notes. Rockville, Maryland: National Institute on Drug Abuse.

Gentilello, L. M., Rivara, F. P., Donovan, D. M., Villaveces, A., Daranciang, E., Dunn, C. W \& Ries, R. R. 2000. Alcohol Problems in Women Admitted to a Level I Trauma Center: A Gender Based Comparison. The Journal of Trauma. 48(1): 108-114. doi: 10.1097/00005373200001000-00018.

Gilligan, R. 1995. Family Support and Child Welfare: Realising the Promise of the Child Care Act. In H. Ferguson, and P. Kenny, (Eds.) On Behalf of the Child, Child Welfare, Child Protection and the Child Care Act, Farmer, Dublin. 60-84.

Guo, J. P. D., Hill, K. G. P. D., Hawkins, J. D. P. D., Catalano, R. F. P. D., \& Abbott, R. D. P. D. 2002. A Developmental Analysis of sociodemographic, Family, and Peer Effects on Adolescent Illicit Drug Initiation. Journal of the American Academy of Child \& Adolescent Psychiatry. 41(7): 838-845. doi:10.1097/00004583-200207000-00017.

Gruber, K. J., \& Fleetwood, T. W. 2004. In-home Continuing Care Services for Substance Use Affected Families. Substance Use \& Misuse. 39(9): 1370-1403. doi:10.1081/JA-120039395.

Hairunnaja Najmuddin. 2007. Memahami dan Membimbing Remaja Nakal. Bentong: PTS Publications \& Distributors Sdn. Bhd.

Keen, J., Oliver, P., Rowse, G. \& Mathers, N. 2000. Keeping the Families of Heroin Addicts Together: Results of 13 Months' Intake for Community Detoxification and Rehabilitation at a Family Centre for Drug Users'. Family Practice. 17(6): 484-489. doi: 10.1093/fampra/17.6.484.

Kumpfer, K. L, Alvarado R., \& Whiteside, H. O. 2003. Family-based Interventions for Substance Use and Misuse Prevention. Substance use and misuse. 38 (11-13): 1759-1787. doi: 10.1081/JA-120024240.

Laporan Dadah Malaysia. 2002. Kuala Lumpur: Agensi Anti Dadah Kebangsaan.

Lerner, R. M., \& Galambos, N. L. 1998. Adolescent Development: Challenges and Opportunities for Research, Programs and Policies. Annual Review of Psychology. 49: 413-444. doi: 10.1146/annurev.psych.49.1.413.

Lila, M. S. \& Gracia, E. 2005. Determinantes de la aceptación-rechazo parental [Determinants of parental aceptancerejection]. Psicothema, 15(2): 161-166.

Mahmood Nazar Mohamed. 1996. Peranan \& Penglibatan Keluarga dan Masyarakat Dalam Pencegahan Penagihan Berulang. Jurnal PERKAMA. Bil.6.ISSN 0127/6301. Terbitan Persatuan Kaunseling Malaysia.

Mackay, R. 2003. Family Resilience and Good Child Outcomes: An Overview of the Research Literature. Social Policy Journal of New Zealand. 5(1): 65-76.

Malhotra, N. K., Hall, J., Sham, M \& Crsip, M. 1996. Marketing Research: Applied Orientation. ( $1^{\text {st }}$ Edition). Sydney: Prentice Hall

Mann, K., Hintz, T., \& Jung, M. 2004. Does Psychiatric Comorbidity in Alcohol-dependent Patients Affect Treatment Outcome? European
Archives of Psychiatry and Clinical Neuroscience. 254(3): 172-181 doi:10.1007/s00406-004-0465-6.

McIntosh, J., MacDonald, F., \& McKeganey, N. 2005. The Reasons Why Children in Their Pre and Early Teenage Years Do or Do Not Use Illegal Drugs. International Journal of Drug Policy. 16(4): 254-26. doi:10.1016/j.drugpo.2005.05.005.

Miller, N. S., Ninonuevo, F., Hoffmann, N. G., \& Astrachan, B. M. 1999. Prediction of Treatment Outcomes: Lifetime Depression Versus the Continuum of Care. American Journal on Addictions. 8(3): 243-253. doi:10.1080/105504999305857.

Moos, R. H., \& King, M. J. 1997. Participation in Community Residential Treatment and Substance Abuse Patients' Outcomes at Discharge. Journal of Substance Abuse Treatment. 14(1): 71-80. doi.org/10.1016/S0740-5472(96)00189-4.

Musitu, G., Buelga, S., Lila, M. S., \& Cava, M. J. 2000. Familia y Adolescencia. [Family and Adolescence]. Madrid: Síntesis.

Najavits, L. M., Weiss, R. D., \& Shaw, S. R. 1997. The Link Between Substance Abuse and Posttraumatic Stress Disorder in Women. A Research Review. American Journal on Addictions. 6(4): 273-283. doi:10.3109/10550499709005058.

Painter, J., Riley-Buckley, D. \& Whittington, D. 2000. Practical considerations: Making women's services available. Druglink. 15(5): $18-20$

Phillips, J., Carpenter, K. M., \& Nunes, E. V. 2004. Suicide Risk in Depressed Methadonemaintained Patients: Associations with Clinical and Demographic Characteristics. American Journal on Addictions. 13(4): 327-332.

Poole, N. \& Dell, C. A. 2005. Girls, Women and Substance Use. Ottawa: Canadian Centre on Substance Abuse \& BC Centre for Excellence for Women's Health.

Rohayati Derani. 2004. Persepsi Ibu Bapa Terhadap Faktor-Faktor Keruntuhan Akhlak Remaja Islam Masa Kini: Satu Tinjauan di Taman Aman Anak Bukit, Alor Setar Kedah. Ijazah Sarjana Muda Sains Serta Pendidikan (Pengajian Islam). Johor: Fakulti Pendidikan, Universiti Teknologi Malaysia

Saunders, B. \& Allsop, S. 1987. Relapse A Psychological Perspective. British Journal of Addiction. 82(4): 417-429. doi: 10.1111/j.13600443.1987.tb01497.x.

Saxe, G., \& Wolfe, J. 1999. Gender and Posttraumatic Stress Disorder. In P. A. Saigh \& J. D. Bremner (Eds.). Posttraumatic Stress Disorder: A Comprehensive Text. Boston, MA: Allyn and Bacon. 160-182.

Sheridan, M. J. 1995. A Proposed Intergenerational Model of Substance Abuse, Family Functioning, and Abuse/Neglect. Child Abuse \& Neglect. 19(5): 519-530. doi:10.1016/0145-2134(95)00012-W.

UNODC. 1995. The Social Impact of Drug Abuse. http://www.unodc.org/pdf/technical_series_1995-03-01_1.pdf. Diakses pada 20 Februari 2013

Velleman, R. B., L. J. Templeton and A. G. Copello. 2005. The Role of the Family in Preventing and Intervening with Substance Use and Misuse: A Comprehensive Review Of Family Interventions, with aFocus on Young People. Drug and Alcohol Review. 24(2): 93-109.

Vimpani, G. 2005. Getting the Mix Right: Family, Community and Social Policy Interventions to Improve Outcomes for Young People at Risk of Substance Misuse. Drug and Alcohol Review. 24(2): 111-125. doi:10.1080/09595230500102210

Willson, J. Q., \& Kelling, G. L. 1982. Broken Window's. Atlantic Monthly. Mac 1982: 29-38.

Williams, R. J., McDermitt, D. R., Bertrand, L. D., \& Davis, R. M. 2003. Parental Awareness of Adolescent Substance Use. Addictive Behaviors 28(4): 803-809. doi:10.1016/S0306-4603(01)00275-1.

Woods, M. 1999. Women, Drug Use and Parenting in Dublin: The Views of Professional Workers in the Drug Treatment and Social Work Fields in Ilicit Drugs: Patterns of use - Patterns of response, Proceedings of the 10th Annual ESSD Conference on Drug Use and Drug Policy in Europe, held in Vienna in September 1999. 275-289.

Zimmermann, G., Pin, M. A., Krenz, S., Bouchat, A., Favrat, B., Besson, J., \& Zullino, D. F. 2004. Prevalence of Social Phobia in a Clinical Sample of Drug Dependent Patients. Journal of Affective Disorders. 83(1): 83-87. doi:10.1016/j.jad.2004.05.003. 